УДК 338

DOI: 10.17277/voprosy.2017.01.pp.106-110

\title{
THE COMPREHENSIVE COMPARISON BETWEEN RADICAL AND GRADUAL WAYS OF REFORM FROM THE PERSPECTIVE OF "COST-BENEFIT"
}

\author{
Sai Xiaoxu \\ Shandong Normal University, Jinan, China \\ Reviewed by Doctor of Economic Sciences, \\ Professor N. V. Zlobina
}

Keywords: cost-benefit; gradual reform; radical reform.

\begin{abstract}
Abastract: In the economic field, the comparison between the radical reform and the gradual reform has been debated for a very long time. Radical reformers and gradual reformers have different opinions from the perspective of "cost-benefit". While the radical reformers and the gradual reformers differ in many ways, such differences are neither superior nor inferior to each other. Only selecting the reform that is suitable to its national conditions does turn to be the most optimal choice.
\end{abstract}

It is an inevitable course for former socialist countries to realize modernization by getting rid of the constraint of the traditional highlycentralized planned system and transferring to the market economy. On the basis of summarizing lessons learned from the past and the present, the former Soviet Union, Eastern European countries and China have all chosen to carry out the market-oriented economic reform. The difference is that these countries have selected two different ways of transformation. Countries represented by Russia, Poland etc. resorted to the radical way of reform, while countries like China, Vietnam, and Hungary etc. adopted the gradual way of reform. For more than 20 years, worldwide scholars have carried out extensive and everlasting debates on the question: Which reform way is superior? Two completely different opinions have been formed. Some scholars represented by Sax, Yongtai Hu,Xiaokai Yang, Wuchang Zhang, Kornai etc. support the radical way of reform. Some represented by Stiglitz, Norton, ChenggangXu, Yifu Lin, MinHuaetc. favor the gradual approach of reform. Therefore, the comparison between two reforms becomes a difficult problem that urgently needs to be solved.

Сай Сяосюй - профессор экономического института, Шаньдунский педагогический университет, e-mail: saixxw@sina.com., г. Цзинань, Китайская Народная Республика. 
"Cost-benefit" Definition about the Way of Reform. The "cost-benefit" analysis is one of the methods commonly used in economics. The comparison between the two ways of reform cannot do without the "cost-benefit" analysis. The optimal reform approach undoubtedly contains the lowest cost and highest benefit. However, the problem is that the concepts of cost and benefit used by different scholars do not share the same connotation and extension. Therefore, it is necessary for us to further define them and compare the costs and benefits of the two reforms on this basis.

According to Sheng Hong, if a reform approach brings resource allocation and improves the income of some people but causes the loss of other people, those who lose profits will object to the implementation of approach. There are various ways of objection from complaint, demotivation, social unrest to war, which form the cost of reform. The more people a reform approach harms and the more serious its negative impact is, the higher its cost will be. Thus, the reform cost will be influenced by the number of people negatively affected by the reform, the severity of the negative impact, the number of people against the reform, and the degree of objection [1].

From a vertical angle,Shijin Liu reveals the composition of institutional innovation costs:

1) costs in the innovation preparation stage, including the cost to accept and convey information about institutional disequilibrium and innovation potential gains, the cost to organize innovative groups, and the cost to design, compare and select innovative schemes;

2) costs during the system transition stage, covering the cost caused by conflicts between new and old systems as well as the non-collaboration and resistance from people who suffer from benefit loss;

3 ) costs in the improvement of new system stage, containing the cost to establish the legal system to ensure the legitimacy of the new system, and the cost to standardize ways to enable the new system organized and operated [2].

In the early 1990s, Yuesheng Wang discussed the cost to transfer to the market economy from a unified economic and non-economic angle, and then put forward concepts of "economic hurdles" and "non-economic hurdles". "Economic hurdles" refer to difficulties about changing the already existing property relations, enterprise system, price system and financial system, and it also refers to difficulties related to maintaining the balance between macroscopic equilibrium and production level during the transition period. As for "non-economic hurdles", it means that some interest groups may object to the reform for their own interests. Marketization exerts an influence on already existing property relations, social structure, hierarchy and power base, which leads to huge changes to the entire social and political system. Meanwhile, social problems, such as large-scale unemployment, rising prices, wealth polarization, and strikes may occur during the process of economic marketization. Objectors may utilize those problems with the aim of threatening social stability [3].

Starting from "social cost" and "social benefit", Gang Fan defines reform benefit and reform cost as the increase and deduction of national income respectively. From the angle of causes and characteristics of cost he divides reform cost into "implementation cost" and "frictional cost". "Implementation 
cost" refers to losses of economic efficiency caused by "incomplete information", "incomplete knowledge" and "unstable system expectation". It is economic losses caused by the design, innovation and adjustment process from the transition between old system and new system. Such a transition covers the structures and functions of various economic organizations, and formal and informal systems, regulations and rules between different organizations. In other words, it is the transaction cost to implement the new system. "Frictional cost" means that the nature of economic system reform is to change the interest relationship among people, and such a process may damage some people's interests to some extents. Due to the "non-pareto change" feature of reform, the reform inevitably be resisted and objected by some people in the society, which intensify social conflictsand thereby cause economic losses. In brief, "frictional cost" refers to economic losses caused by the resistance and objection of some interest groups against the reform [4].

In comparison, Gang Fan's analysis is more concise and practical. First, although the loss of national income does not represent the whole reform cost, the loss of national income can be utilized as an index to measure the reform cost. The index not only truly solves the problem that the reform cost is hard to be measured and compared, but also makes it possible to compare the two ways of reform. Secondly, regarding the reform as a process to unify politics and economics, he explores the political and technical costs of reform, which not only reveals different features of reform costs under different reform patterns, but also overcomes the drawback of viewpoints that only focus on one kind of cost but ignore the other. Thirdly, Gang Fan's analysis avoids generalizations by associating reform cost with specific historical conditions, drawing more practical and reasonable conclusions in the end.

From the Perspective of "Cost-benefit", the Radical and Gradual Ways of Reform are Neither Superior nor Inferior to Each Other. According to Gang Fan's analysis, implementation cost is the decreasing function of reform radicalness. The faster the reform is implemented, the less time the reform needs, the more thoroughly signal distortion problems can be corrected. Meanwhile, the faster the society build a new system, the faster people form perceptions about a new system and gain new stable expectation, and the less loss the economy faces, and vice versa. If only focus on minimizing implementation costs, it seems that "one-step" radical reform is superior to gradual reform. However, frictional cost is the increasing function of reform radicalness. The more radical the reform is pursued, the faster an old system is broken. The previous interest relationship can be changed in a qucik and wideranging way, and the reform encounters intense social barriers, resuliting in fierce social conflicts and rise in fractional costs, and vice versa. If only focus on minimizng fractional costs, gradual reform turns to be more superior relative to radical reform.

It is a consensus that the frictional cost of radical reform is greater than the gradual reform, but there is a disagreement that wether the implementation cost of gradual reform is greater than the radical reform or not. Gradual reform is able to increase the implementation cost, but it also has the internal tendency to reduce the implementation cost. First of all, gradual reform is able to lower the cost caused by design errors. Secondly, gradual reform avoids destructions of 
information and organization so as to reduce organization costs and information costs. Moreover, compared to the large-scale and all-round reform based on rational design, gradual reform adopts the bottom-up plans step-by-step, which reduces the demand of information, saves information costs, and improves reform's benefits. Fourthly, gradual reform with the marginal feature is able to reduce contracting costs because reforms with large resistance can be postponed or dispesed into small acts. Lastly, gradual reform occours in the situation where the old system faces the worst crisis, the lowest opportunity cost and the highest return, thereby the crisis in the old system helps to conclude the transaction by lowering the transaction cost. Therefore, the relationship between the implementation cost, the degree of radical reform and the length of reform is extremely complicated. Due to the inability to conducting the accurate quantitative analysis, it is hardly to confirm the hypothesis that the implementation cost of gradual reform is greater than the radical reform. If factors in favor of reducing the implementation cost are utilized in the analysis, it still can be hardly proved that the implementation cost of gradual reform is lower than the radical reform or both costs are roughly equivalent [5].

Generally speaking, the most prominent merit of radical reform lies in shortening the time of system transition, which lays the foundation for the longterm development of national economy. The most shortcoming of gradual reform is the co-existence and friction of dual-track system, resulting in the distortion of economic signal, disorder of economy, macro-instabilities, illegal tradeoff of money and power. Such consequences exert negative impacts on the efficiency of resource allpcation, and breeds a new interest group benefited from the dual-track system. The new interest group not only becomes the resistance of reform, but also produces social conflicts. The longer the transitional period, the higher the cost to be paid, which is the reason why people tend to approve the dual-track system instead of objecting it. Besides, the short-term cost of gradual system is less than the long-term cost. The gradual reform is from easiness to hardness: with the development of reform, the risk and difficulty of reform is on the increase. For this reason, if we insist on applying "dichotomy" to interpret radical reform and gradual reform, we will prove that the implementation cost of gradual reform is greater than the radical reform.

Due to the two kinds of cost in reform scheme instead of only one, especially when these two costs is different from the "reform speed", it is hard for us, in theory,to prove which reform approach is superior than another unconditionally. Under different circumstances, both approaches can be the most optimal choice. The radical reform suffers less loss of efficiency, but the gradual reform has lower fracitonal costs. Only by takingdifferent conditions and issues in different economic reformsinto consideration can we elaborate in a more spefic way to determine which reform is better.

Conclusion. In terms of radical and gradual reform, both of them have advantages and disadvantages. It does not make any sense if we ignore the specific and objective conditions and compare the two reforms in the abstract. Based on the reality, selecting the transition path that is suitable to its national conditionsturns to be the most optimal choice. Opinions such as radical reform is superior to gradual reform or gradual reform is better than radical reform are theoretically partial, which can not withstand the test of time and practice. 
The article is the phased achievement of "Economic Analysis of the Public Economy Development" Project of Shandong Social Science Planning Project and "Research on 'Insider Control' in System Transformation" Project of Shandong Provincial Department of Education.

\section{References}

1. Sheng H. The transition of Chinese economics, Shanghai: Shanghai People's Publishing House, 1995.

2. Liu, S. The Conditions, Process and Cost of the economic system innovation, Economic Research, 1993, no. 3, pp. 56-57.

3. Wang Y. Re-interpretation of Costs and Benefits of Reform under Different Reform Modes, Economic Research, 1997, no. 3, p. 38.

4. Fan G. The Costs and Modes of Two Reforms, Economic Research, 1993, no. 1, p. 3-8.

5. Zhang K. The Market as the System and the System behind the Market, Lixin: Lixin Accounting Press, 1996.

\section{Список литературы}

1. Sheng, H. The transition of Chinese economics / Hong Sheng. - Shanghai : Shanghai People's Publishing House, 1995.

2. Liu, S. The Conditions, Process and Cost of the economic system innovation/ Shijin Liu // Economic Research. - 1993 - No. 3. - P. 56 - 57.

3. Wang, Y. Re-interpretation of Costs and Benefits of Reform under Different Reform Modes / Yuesheng Wang // Economic Research. - 1997. - № 3. - P. 38.

4. Fan, G. The Costs and Modes of Two Reforms/ Gang Fan // Economic Research. 1993. - No. 1. - P. 3 - 8 .

5. Zhang, K. The Market as the System and the System behind the Market / Kenan Zhang. - Lixin : Lixin Accounting Press, 1996.

\section{К вопросу об эффективности радикальной и постепенной реформы экономики}

\section{Сай Сяосюй}

Шаньдунский педагогический университет,

2. Цзинань, Китайская Народная Республика

Ключевые слова: постепенная реформа; радикальная реформа; рентабельность.

Аннотация: Рассмотрена проблема радикального и постепенного реформирования экономики. Несмотря на наличие противоречий между сторонниками двух путей реализации экономической реформы с точки зрения их эфеективности, эти различия не являются существенными. Отмечается необходимость учета национальной специфики при выборе оптимального пути экономического развития. 